\title{
Economic Analysis for Internet Industry in China
}

\author{
Wei Huan \\ China Center for Industrial Security Research, BeiJing 100044, China \\ weihuancn_2013@126.com
}

\begin{abstract}
With the popularity of Internet networks, its impact in people's production and life increasing broadly. Based on internet, network economy as a symbol of the network industry has developed rapidly in our country. Analysed the status of the network economy, investigated the positive and negative implications of the network economy to the Chinese economy, pointed out the problems of network economy, and made recommendations to the future development of network economy.

Index Terms - Network Economy, Information Industry, Ecommerce.
\end{abstract}

\section{Introduction}

Since 1993, with the fast development of the Internet and business applications, the Internet economy rapid developed of the first time in the United States and then spread to the world. In front of the trend of rapid development of global networks, China's Internet industry is spread in a same way. In the early 1990s, our government has implemented the "Golden Bridge", "Gold Card" and a series of gold projects. Under the world's context of building "information superhighway" in developed countries. our country's IT experts made our own "high-speed information network plan" in accordance with China's national conditions[1], in October 15, 1993, the world's longest optical cable, the communication "aortic" runs through north and south of China's Jing-Han-Guang all opened, opened China's network infrastructure prologue.

China formally communicated with the Internet on April 1994, with the built of public network, education and research network, science and technology network and Jin-qiao network the economy driven by information technology, the Internet economy. China's enterprises started e-commerce since 1994, and has made gratifying achievements. The year1998 is the world's e-commerce year, China had set off a wave of e-commerce heat, and China Commodity Market officially entered the Internet from one July 1998 [2].

On March and April of 2000, the U.S. Internet stocks started to fall significantly. In this year, the network index just share a quarter of the highest point, the more tragic was a smash hit Internet companies were bankruptcy. However, since 2003, China's Internet economy showed strong signs of recovery, suggesting through big waves the network economy step into a new period of development after the baptism. Start.

This table shows the differences between traditional economic characteristics and network economic characteristics. From the perspective of macro and micro, network economy had a huge effect on China's economy. It is obvious that in some degree network economic is better than traditional economic, and it is more popular than traditional economic.
Table 1 Comparisons of traditional economy and network economy

\begin{tabular}{|c|c|c|c|}
\hline scope & & $\begin{array}{l}\text { Traditional } \\
\text { economic } \\
\text { characteristics }\end{array}$ & $\begin{array}{l}\text { Network } \\
\text { economic } \\
\text { characteristics }\end{array}$ \\
\hline \multirow[t]{4}{*}{$\begin{array}{l}\text { Micro } \\
\text { perspective }\end{array}$} & information & $\begin{array}{l}\text { Obsolete, } \\
\text { redundant }\end{array}$ & $\begin{array}{l}\text { Real-time, } \\
\text { accurate }\end{array}$ \\
\hline & $\begin{array}{l}\text { The industrial } \\
\text { chain }\end{array}$ & $\begin{array}{l}\text { Static, path } \\
\text { dependence }\end{array}$ & $\begin{array}{l}\text { Dynamic, self } \\
\text { adjusting }\end{array}$ \\
\hline & $\begin{array}{l}\text { Basic } \\
\text { technology }\end{array}$ & Transport & Information \\
\hline & Flow cost & High & Low \\
\hline \multirow[t]{3}{*}{$\begin{array}{l}\text { Medium } \\
\text { perspective }\end{array}$} & $\begin{array}{l}\text { Public } \\
\text { awareness }\end{array}$ & Passive & Active \\
\hline & $\begin{array}{l}\text { Enterprise } \\
\text { image }\end{array}$ & Fuzzy & Clear \\
\hline & $\begin{array}{l}\text { Government } \\
\text { system }\end{array}$ & Segmentation & Unobstructed \\
\hline \multirow[t]{2}{*}{$\begin{array}{l}\text { Macro } \\
\text { perspective }\end{array}$} & Spatial structure & Center gathered & $\begin{array}{l}\text { Peer-to-peer } \\
\text { networks }\end{array}$ \\
\hline & location & Space distance & $\begin{array}{l}\text { Perception of } \\
\text { distance }\end{array}$ \\
\hline
\end{tabular}

According to the latest statistics of China Internet Network Information Center (CN2NIC)[3], the number of Internet users in China's Internet rose from 68 million to 79.5 million after six months in December 31, 2003, compared with the same period in 2002, maintaining a high growth rate of $35 \%$, ranked second in the world. The number of Internet computers rose from 2572 million to 30.89 million through six months, compared with the same period in 2002, maintaining a high growth rate of 48 percent. WWW site number is 595,550 , has an increase of 121,650 within six months and an increase of 25.7 percent, and has an increase of 60.3 percent over the same period of 2002. Registered names under CN domain is 340,040 , the total international bandwidth capacity is $27216 \mathrm{Mbps}$, has an increase of $8617 \mathrm{M}$ compared with six months ago and a growth rate of 46.3 percent, and an increase of 190.1 percent over the same period of 2002, and was 1071 times of 1997's survey results.

First, the relevant departments to further promote information technology. In 2003, with all levels of government change and promote to a service-oriented government, e-government as an important feature of the planning of service-oriented government into implementation year. According to CNNIC's latest statistics, government websites up to 32 percent over last year by growing 15 percentage points [4]. The development of e-government network will provide strong support for economic development and bring new opportunities for the development of the network economy. Secondly, the business forward further development of Internet applications. 
According to CNNIC's statistics, the number of corporate websites owns the largest proportion of the total site, reaching 70.9 percent [5], followed by was commercial sites, accounting about 8.2 percent. The number of sites under COM.CN increased 69,432 in six months has an increase of 20.3 percent. Again, users morphological are difference. According to CNNIC's survey, Internet users direction is to a reasonable and balanced structure, there are diversification means of access, dedicated Internet access, ISDN and broadband internet access [6] has emerged as the number of users is in fast growing trend, growing number of families received network, the Internet sites of users is expansion, purpose of the Internet continues to diversify.

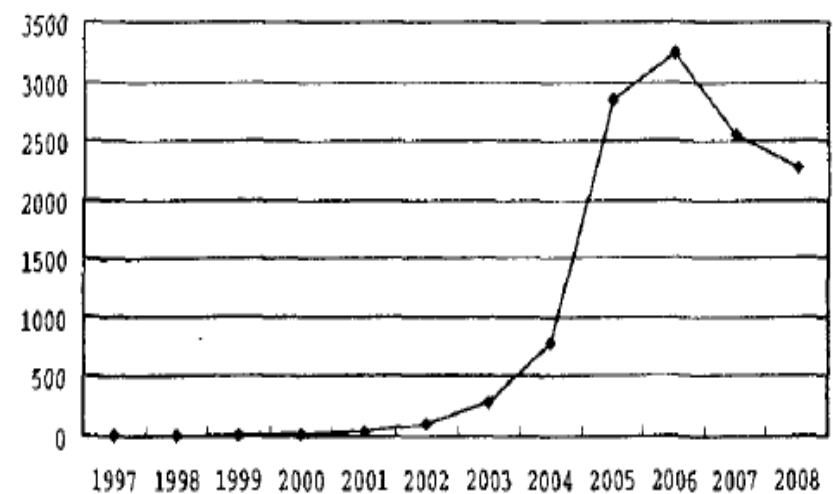

Figure 1 The number of companies using network economy

According to the survey, online advertising, online messaging, online games promoting the rapid development of the Internet industry, and the search engine, free e-mail, online shopping, broadband services and other new network services is on the rise, on behalf of the diversification development trend of network economic.

\section{Impact of Network economy on China's economy}

Network economy is an information market economy, has great potential for development. After more than ten years of development, China's information network has been basically covered national economic sectors, with the promotion of government and enterprises network's, the network economy emerged. From the perspective of macro and micro, network economy had a huge effect on China's economy.

Enhance various elements of the productivity. Internet as a new basis structure of future social, by enhancing information awareness and information activities of workers, enhancing the quality of workers, through digital technology improve the quality of tools and labor and to expand the scope via the network, creating new object of labor, to raise the overall productivity of the elements. Internet will create new physical and virtual environments for capital, goods, information and knowledge flows of China economy and the world [7].

The rise and the rapid development of the Internet has changed the traditional information collection, transmission and processing methods, production, distribution, consumption and other market information are transparency than ever before, but also generally improved the worker's labor skills and work efficiency, while the network could transform traditional industries be represented of Manufacturing technology, made new modes of integration of integrated manufacturing and intelligent manufacturing systems of the modern computer become the development direction, China enterprises produce agility and adaptability greatly improved, high quality and low cost products and services will really improve the competitiveness of Chinese enterprises on a larger scale.

Internet has changed the traditional business mode of production, forms of organization, management, business strategy, trade channels and marketing concepts, resulted virtual enterprise. Network organization makes business activities run more rapidly, reduce administrative costs and marketing costs.

In the new economy, network products and services continue to decline in the price level, quality and performance continue to improve, so that our country can pay less to purchase and install advanced computer and network equipment of the world and use more sophisticated software systems, that is using the "advantages" to achieve competition with developed countries in the same way [8]. On the other hand, through modern information technology to do some transformation of China's traditional industries with comparative advantages as well as finance, insurance, trade and industry, so that these industries regain competitiveness again.

In our process development of network economy, will inevitably bring great changes in income distribution, the performance is at different levels of education, and different occupations, particularly income gap between urban-rural will widen seriously. To China's traditional industries, the network will enable that business who cannot provide first-class products and services in difficulties or bankruptcy, lost to survive in the excess capacity world production.

Network economy diluted the concept of country, with a strong "supranational nature" and globalization features, will have an impact to our accustomed management system and policies [9]. On the one hand, governments set the various restrictive policies based on their own "special" will be replaced by uniform rules of international organization; part of the power will be transferred to international organizations. On the other hand, the reasons for government do some state interventions based on the "information asymmetry" become pale, because the network economy provides strong technical support and information, so that the possibility of the "market failure" greatly reduced. A significant impact on China's cultural and social management will be inevitable.

It can be seen from the Fig 2 that Network economy as information market economy has great potential for development. With the promotion of government and enterprises network's, China's information network has been basically covered national economic sectors, the network economy emerged. 


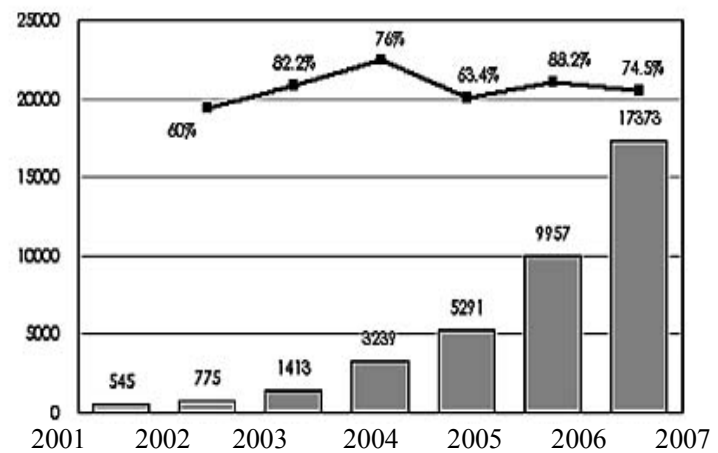

Figure 2 The overall development and forecast of Chinese e-commerce market

\section{Problem and thinking for the development of network economy in China}

China's Internet economy is step into e-commerce era, the Internet's security is closely related to huge economic interests in the era of in e-commerce, network security, personal information, and credit problem is getting people's attention.

E-commerce site topped the standings of the hacker hits, unauthorized access, information theft and misappropriation, fraud and extortion information, information attacks and damage electronic assault, parasitic viruses or broken program.

Companies collect people's consumption behaviour data, demographic data, and psychological records and other data, and then through the data warehouse to determine customers' individual needs. The data collected triggered a privacy issues. In e-commerce, the control of information of consumers is limited, individual's privacy in the most dangerous situation during the process of online ordering.

Credit has also become obstacles to the development of network economy at the age of electronic commerce. When consumers online shopping with the two sides of B2B transactions have biggest concern with risk exists in credit card theft. From e-commerce payment's process can be seen, the risk of online payment process is a hinder of e-commerce development.

Further to strengthen the study and understanding of the network economy, in particular research the applied of network economic development and make economic development trends of the network with the running reality of our economy closely together, explore the reality of China's economy and development of network economy docking problem. Specifically, accelerate the development pace of our network economic, the following issues should be resolved:

Strengthen the infrastructure of network economic vigorously is much important. Based on learning and absorbing foreign advanced network economy infrastructure experience, adopt effective policies and measures to improve and strengthen our strong network economic infrastructure for our network infrastructure economic realities.

To establish a team to adapt to the requirements of network economic development and form safe, efficient network technology to ensure the economic development of the system. On the basis of depth analysis and understanding of the quality of workers required to the network economic development in the new century to develop and implement the personnel training programs to meet requirements of network economic development, training and creating a large number of high-quality people of development of network economy. On the basis of fully understand and learned the domestic in the lessons of international network economy, combined with our Internet business characteristics research and develop technical support system to adapt to the requirements of our network economic development to ensure the economic security of the network.

Based on extensive research, selected a representative sample of industries or enterprises as network transformation pilot, encouraged enterprises to access, guiding enterprises to make full use of the Internet network's advantage, achieved good economic and social benefits.

On the basis of conscientiously sum up networks economic development experience in domestic and international, combined with China's national conditions and business Internet requirements, accelerate the formulation and implementation of network policies and regulations which conducive to economic development, and provide a relaxed policy environment and legal protection of the development of China's Internet economy.

\section{Conclusions}

Network economy is an information market economy, has great potential for development. According to the survey, online advertising, online messaging, online games promoting the rapid development of the Internet industry, and the search engine, free e-mail, online shopping, broadband services and other new network services is on the rise, on behalf of the diversification development trend of network economic.

Pointing out the problems of network economy, and made recommendations to the future development of network economy. After more than ten years of development, China's information network has been basically covered national economic sectors, with the promotion of government and enterprises network's, the network economy emerged. From the perspective of macro and micro, network economy had a huge effect on China's economy.

\section{References}

[1] Han Ping. Impact of Information Technology's to China's Internet economy operating environment. Technology progress and countermeasures, 10, 2005.

[2] $\mathrm{Li} \mathrm{Sa}$. Networked manufacturing promotes regional economic development. China's manufacturing information. 12, 2005.

[3] Liu Jianhui, Chen Anyang. The status and influence of our country's network economic development. Information industry, 3, 2005.

[4] M. King, B. Zhu, and S. Tang, "Optimal path planning," Mobile Robots, vol. 8, no. 2, pp. 520-531, March 2001.

[5] Lu Donghai. E-commerce is the key to enhance the core competitiveness in the era of the Internet economy. Jiangsu Commercial Forum, 2005

[6] Ren Weiping, Li Xihua. Economic Imperialism. Economist, 2, 2003.

[7] Wang Haibo. Research on the Network Security and Network Economy. Group Economic Research, 9, 2005.

[8] Wang Ling. network economy - the inevitable trend of social and economic development. Economist. 1, 2006.

[9] Wang Yansong. Internet economy and its impacts on society. Technology Information. 23, 2005. 